Northwestern University School of Law Northwestern University School of Law Scholarly Commons

Faculty Working Papers

1965

\title{
The Neo-Positivist Concept of International Law
}

Anthony D'Amato

Northwestern University School of Law, a-damato@law.northwestern.edu

\section{Repository Citation}

D'Amato, Anthony, "The Neo-Positivist Concept of International Law" (1965). Faculty Working Papers. Paper 121.

http://scholarlycommons.law.northwestern.edu/facultyworkingpapers/121 
The Neo-Positivist Concept of International Law, by Anthony D’Amato, 59 Am. J. Int’l. Law, 321-324 (1965)

\begin{abstract}
The question "Is international law really law?" has not proved troublesome, according to Hart, because "a trivial question about the meaning of words has been mistaken for a serious question about the nature of things." Hart defends international law in Bentham's terms as "sufficiently analogous" to municipal law. It is important to see in what way this analogy is viewed by Hart in order to determine whether the reasoning he offers is too high a price to pay for accepting a neo-positivist into the circle of those who hold that international law is really law.
\end{abstract}

Tags: Rule of Recognition, Sovereignty, Neo-Positivism, International Law, Basic norm in international law, Hart (H.L.A.)

[pg321] The question "Is international law really law?" has not proved troublesome, according to Professor H. L. A. Hart, simply because "a trivial question about the meaning of words has been mistaken for a serious question about the nature of things." [FN1] His examination of this problem in The Concept of Law deserves a greater measure of critical scrutiny than it has received, partly because of the increasing recognition that his book is destined to become a milestone in jurisprudence and partly because of the way in which he reaches a generally acceptable conclusion. Unlike his predecessor Austin's claim that international law was merely positive morality, Professor Hart defends international law in Bentham's terms as "sufficiently analogous" to municipal law.[FN2] It is important to see in what way this analogy is viewed by Professor Hart in order to determine whether the reasoning he offers is too high a price to pay for accepting a neo-positivist into the circle of those who hold that international law is really law.

Professor Hart's argument deals with two principal sources of doubt arising from the claim that international law is somehow less real than municipal law. The first is easily dealt with: how international law can be binding upon sovereign states. At an early stage in his book Professor Hart disclaims the usefulness of "sovereignty" in describing any legal system. When he turns to international law, he adds the further argument that "sovereign" means no more than "independent." Thus we must look to the rules of international law to see just how far this independence extends.

The second doubt is how international law can, in the absence of organized international sanctions, be binding in the same sense as ordinary municipal law. Professor Hart argues that, although in any legal system obligation is generally congruent with a likelihood of sanctions for disobedience, there is no necessary relation between the two. Nor are sanctions "necessary" to a legal system, for while they may be used in municipal law against an expected minority of malefactors without too much risk, in international law sanctions may lead to widespread and self-defeating international strife. Whatever differences exist do not overcome the fact that international law is thought and spoken of as obligatory, that it gives rise to claims and admissions couched in legal terms, and that when rules of international law are disregarded, states attempt to show that the facts are not as claimed (or, it may be added, that the rules do not apply to the alleged facts), rather than that the rules are not binding.

Thus, summarized, Professor Hart's position appears to be one with [pg322] which few would substantially disagree. Nevertheless each of his arguments entails a line of reasoning 
which may lead to undesirable implications for international law. In his first line of argument, Professor Hart finds "sovereignty" unnecessary to neo-positivism because there is a more illuminating tool of analysis which he labels the "rule of recognition." By this he means the rule or rules in a society which confer power upon lawmakers. This rule makes it possible to identify sources of law. The rule of recognition is more fundamental than the notion of sovereignty since it tells who the sovereign is and how his power can be transferred. Yet in his consideration of international law, Professor Hart argues that there is no unifying rule of recognition specifying "sources" of law and providing general criteria for the identification of its rules. This argument runs parallel to his view that there is no proper sense of "sovereignty" in international law other than "independence."FN3 But if international law lacks a rule of recognition, how can it still be termed "law"? Professor Hart's answer appears to be that international law is still primitive: it is a set of rules, not a system. Yet it is no less "law" since there is a great range of principles, concepts and methods which are common to both municipal and international law and which make a lawyer's technique freely transferable from one to the other. Perhaps, Professor Hart adds, if multilateral treaties were to be generally recognized as binding upon states that are not parties to them, such treaties would become legislative enactments and thus international law would be provided with a distinctive criterion of validity for its rules. The advent of such a rule of recognition would lay to rest the skeptic's last doubts that international law is really law.

This argument of Professor Hart is disturbing in that international law becomes law at the price of conceding that it is a primitive kind of law lacking in "rules of recognition." His conclusion will certainly be challenged by those who agree with his analysis of rules of recognition but consider that they are more fundamental than he does. More significantly, Professor Hart's argument may suggest that international law is basically incomplete and thus deserving of less respect on the part of states than ordinary municipal law.

A closer look at the idea of rules of recognition is therefore in order. When does the rule of recognition arise which transforms a primitive society into a modern legal system? How does it arise? Once it has arisen, can it be revoked? Professor Hart does not appear to give a satisfactory answer to these questions, which are analogous to questions one might ask about a theory of sovereignty. Further, how does the rule of recognition cope with the possibility of an abuse of authority on the part [pg323] of the lawmakers? Professor Hart's answer to this appears to be that the authority conferred by the rule cannot be withdrawn even if the rule is abused. But if this is true, it would not take long for a legislator to change or manipulate the rules of recognition at whim. Additionally, as Professor Fuller points out, Professor Hart seems saddled with the necessity of excluding from a rule of recognition any express or tacit provision to the effect that the authority it confers can be withdrawn for abuses of it, such a provision might seem to impose a duty upon the legislator-an idea contrary to Professor Hart's definition of the rule of recognition as solely a power-conferring rule which cannot give rise to duties.FN4

The difficulty with the idea of a rule of recognition is that it mistakenly tries to account for sociological fact (how and why people obey laws) by the use of legal concepts which necessarily arise after such fact. This point is easily seen in international law. The practice of states which gives rise to rules of international law often reflects shared attitudes about what international law ought to be. States are aware that their actions have legal consequences-that 
their conduct is the raw material of custom and precedent-within a system in which it is generally accepted that their actions ought to have legal consequences. Thus there is an interrelation between law-formation and law-interpretation; the "rules of recognition" of international law, as it were, are a product of the practice of states. Why this has come about is a matter of sociology, but there is no doubt that it does occur.

Professor Hart's own example of multilateral treaties provides a good illustration. His argument is that when multilateral treaties become generally accepted as binding upon nonparties, they will become legislative enactments and thus international law will finally have a rule of recognition. But this argument betrays a longing for a legislative system similar to that in municipal law despite Professor Hart's insistence that international law is "law." How can it be assumed that the extension of rules contained in multilateral conventions to non-parties will necessarily become a sort of "legislation?” These treaties might, on the contrary, be viewed as evidence of custom to be weighed in the balance with other evidence of usage becoming customary obligation. The treaties might be given weight according to the number of states which have ratified each convention, an idea wholly at variance with municipal legislation. But quite apart from these objections, it is apparent that if treaties become a form of international legislation, they will have done so by the operation of the practice of states hardening into law. State practice may accept a form of international legislation or it may not, but the entire legal system is not fundamentally altered thereby. Assigning international legislative consequences to multilateral conventions may be a step in the direction of simplicity, but surely cannot be held to be the [pg324] revolution which transforms primitive international law into a complex system of modern law.

In his second argument that international law is "binding" without organized sanctions, Professor Hart uses the same reasoning to read out of international law any necessary connection with morality per se or with morality induced by sanctions. In addition he uses the conclusion that international law is really law to exclude the classification of international law as "morality" in any normal sense of that word. Although neither of these arguments separating law and morality appears logically compelled by his main arguments on international law, it is nevertheless significant that Professor Hart has made them. They tie in with his general thesis that rules of law are often morally indifferent but are no less rules of law.

While it is true that at least some rules of law in most legal systems may be morally indifferent, to emphasize this too much is to underestimate the contribution of natural law to international law or to misinterpret some of the rules deriving from natural law. Thus Professor Hart rejects the views of Brierly and Lauterpacht that moral obligation is a foundation of international law. Yet to reject this learning may be to discard much of the structure that is common to international law and to classic theories of natural law. Two brief examples may be cited: First, it is possible to argue that the prohibition against unjust wars found in Grotius and many of his contemporaries has persisted as a rule which requires by its own terms a moral or natural-law interpretation. Even in the era of the United Nations there may still be a just war fought solely for self-defense against an armed attack or fought by the international community acting through appropriate United Nations organs against a state which has caused a threat to the peace. If in years to come the idea of threat to the peace is enlarged to include such actions as violation of an arms control treaty or even severe violations of human rights law, natural law 
and morality will have to be taken into account in determining whether the international community is authorized to take action. Second, the rule of pacta sunt servanda cannot always be satisfactorily applied without reference to its moral purpose. Professor Hart suggests that a state may adhere to an onerous treaty because of a long-term interest in preserving confidence in treaties or because it considers that, having received the benefits of a treaty, it is likewise obliged to accept its present burdens. Yet such motivation-which may indeed explain the not quite analogous municipal law contract-is no help in assessing a claim of clausula rebus sic stantibus. But attention to the substance of morality inherent in a prior promise may, in some cases where the circumstances have radically changed, indicate that the prior promise is no longer substantively applicable and that it would be unjust to insist upon strict compliance. One might tentatively conclude that the attempt to apply a positivist Occam's razor to morality or natural law in international law may lead to considerable distortion in its interpretation.

\section{Footnotes}

[FN1] Hart, The Concept of Law 209 (1961).

[FN2] Ibid at 231.

[FN3] In making this claim, Professor Hart is aware of the theories advanced for "basic norm" in international law. Of the two serious candidates, pacta sunt servanda does not account for all obligations under international law, however widely the term "pacta" is construed, while the rule that "States should behave as they customarily behave" says nothing more than that "those who accept certain rules must also observe a rule that the rules ought to be observed," which is only another way saying that these rules are accepted as binding.

[FN4] Fuller, The Morality of Law 137-138 (1964). The author is indebted to Professor Fuller for showing him this work in progress. Although not addressed to the problem of international law, Professor Fuller's book in its entirety takes cogent issue with Professor Hart's insistence on the separation of law and morality. 